\title{
HUMAN-WILDLIFE CONFLICT IN AND AROUND THE SIMIEN MOUNTAINS NATIONAL PARK, ETHIOPIA
}

\author{
Mesele Yihune ${ }^{1}$, Afework Bekele ${ }^{2,} *$ and Zelealem Tefera ${ }^{3}$ \\ ${ }^{1}$ Department of Biology, Debre Markos University, PO Box 269, Debre Markos, \\ Ethiopia. Email: mesyih@yahoo.com \\ ${ }^{2}$ Department of Biology, Faculty of Science, Addis Ababa University, PO Box 1176, \\ Addis Ababa, Ethiopia. E-mail: afeworkbekele@hotmail.com \\ ${ }^{3}$ Afro-alpine Ecosystem Conservation Project, FZS, PO Box. 101428, Addis Ababa, Ethiopia.
}

\begin{abstract}
Human-wildlife conflict in and around the Simien Mountains National Park was assessed using a questionnaire survey of 300 people living in and around the Park during 2005 and 2006. Logistic regression was used to identify important factors. The result indicated that common jackal caused the most pronounced problems $(57.1 \%)$ to the local community compared to other animals. Among the respondents, 27\% reported loss of oxen, cows, donkeys, mules and horses to spotted hyaenas. The Ethiopian wolf, leopard, vervet monkey, hamadryas baboon and crested porcupine caused minimal problems on the local community in the study area. The Park was utilized by $47.9 \%$ of the respondents as grazing land for their livestock. The average period of utilization of the Park as grazing land was $2.03 \pm 0.11$ months. The duration of grazing in the Park was negatively correlated $(r=-0.69, p<0.05)$ with distance from the Park. Among the respondents, 19.1\% collected firewood from the Park. Collection of firewood was negatively correlated with distance from the Park (r $=-0.33, p<0.001)$. Conflict resolution will not be possible without voluntary resettlement of people living in and very close to the wildlife habitat; providing an alternative resource to the community living in the study area will also be essential.
\end{abstract}

\section{Key words/phrases: Human-wildlife conflict, Simien Mountains National Park, utilization}

\section{INTRODUCTION}

Human-wildlife conflict occurs when the needs and behaviour of wildlife impact negatively on humans or when humans negatively affect the needs of wildlife. These conflicts may result when wildlife damage crops, threaten, kill or injure people and domestic animals (Sillero-Zubiri and Switzer, 2001). The conflicts between humans and wildlife are immense in both diversity and number. They involve categories like livestock predation, disease and crop raiding. These are viewed as critical problems created by the growing rural population in and around wildlife habitats (Sukumar, 1989). One of the major groups of human-wildlife conflict in the study area is crop raiding. Crop raiding is not a new phenomenon; it has most likely been occurring since humans first settled down and started practicing agriculture. Different crops are targeted by animals. In some areas, crop raiding by wild animals is a frequent cause of major conflict between wildlife and villagers. This is especially true in areas close to protected areas which harbour large populations of wildlife (Sukumar, 1989).

Human-wildlife conflict incidents are widespread but not evenly distributed because they are dependent on the proximity of wildlife. In addition, different species cause different types of damage at different times of the year. The damage caused has variable effects on the livelihood of households, depending on their level of livelihood security at the time of the incident (Mulonga et al., 2003). One major cause of human-wildlife conflict is increasing human population adjacent to wildlife habitats. As human population increases and the demand for resources grow, the frequency and intensity of such conflicts increases (Newmark et al., 1993). This can be manifested by increasing encroachment to wildlife habitats. As a result, the populations of those species which are unable to adapt to altered habitats may invade the marginal habitats or decline in number (Newmark et al., 1993). Those species that are able to adapt to a changing ecology and survive in agricultural system become involved in direct competition with humans (Kristin and Struhsaker, 1999; Deresse

\footnotetext{
${ }^{*}$ Author to whom all correspondence should be addressed.
} 
Dejene, 2003). Increase in wildlife population in some areas can be considered as another cause of human-wildlife conflict. In the past, expansion of agriculture and plantation were the causes of wildlife damage. However, these days, urban dwellers and other wildlife stakeholders such as investors are also involved in wildlife damage (Messmer, 2000).

The major objective of the present paper is to evaluate the extent of conflict between the local community and wild animals in and around the Simien Mountains National Park, which is one of the natural world heritage sites, highly threatened by the expansion of human activities and related human-wildlife conflict. This study tries to highlight wildlife species that are responsible for crop raiding and livestock predation in and around the Park. In addition, further investigation on the physical and socio-economic factors affecting livestock predation and crop raiding as well as forms of resource use by the community in the Park will be discussed.

\section{MATERIALS AND METHODS}

\section{The study area}

The Simien Mountains National Park (SMNP) represents one of the most outstanding natural scenic areas of the world, listed as one of the World's Heritage Sites (Falch and Keiner, 2000). It has a unique landscape and rich biodiversity with a variety of endemic species. It is located between $38^{\circ} 00^{\prime}-38^{\circ} 12^{\prime} \mathrm{E}$ and $13^{\circ} 12^{\prime}-13^{\circ} 19^{\prime} \mathrm{N}$ (Fig. 1). The area is composed of broad undulating plateau of vast grassy plains ending in spectacular cliffs to the north (Falch and Keiner, 2000).

The Simien Mountains National Park originally had an area of $136 \mathrm{~km}^{2}$. Even though the unique endemism and bio-physical features of the area made SMNP one of the World Heritage Sites in 1996, it was inscribed on the list of World Heritage Sites in danger. This is because of the recent deterioration of the Walia ibex (Capra ibex walie) and the Ethiopian wolf (Canis simensis) population, loss of other biodiversity, agricultural expansion and the impact of road construction (Falch and Keiner, 2000).

The SMNP has different soil associations and weather patterns. Low temperature is recorded in the highlands, especially during the early mornings of the dry season (Hurni, 1986). The rainfall pattern in the Simien Mountains is characterized by a single rainy season that occurs between June and September ranging from $1350 \mathrm{~mm}$ to $1550 \mathrm{~mm}$ based on altitudinal variation (Hurni, 1986).

The vegetation of the Simien Mountains is characteristic of the Ethiopian tropical seasonal highland biome, demonstrating evolutionary links to both Palaearctic and Afro-tropical areas (Hurni and Ludi, 2000). The Simien Mountains consist of a mixture of Afro-alpine woods, heath forest, high mountain vegetation, montane savannah and montane moorland (Hurni and Ludi, 2000). There are over 20 endemic plant species inside and within the buffer zone of the SMNP. Of these, three are exclusively endemic to the Simien Mountains. 21 species of large mammals have been recorded to occur in the area. Of these, Walia ibex, Ethiopian Wolf and Gelada baboon are endemic to the country, as are several rodent species (Hurni and Ludi, 2000).

\section{Sampling design}

A questionnaire survey was conducted in and around the SMNP in 2005 to see the magnitude of human-wildlife conflict. A pilot survey was conducted on 46 individuals who were randomly selected and interviewed to see the appropriateness of the survey and whether the questionnaire could be understood easily. Then, the actual data collection was carried out on 300 people from separate households using a semi-structured questionnaire. Of these, 72 respondents were females and 228 were males. The questionnaire was designed to check whether there is a humanwildlife conflict in the area and to understand the magnitude of the conflict as well as to find out which species are problematic in the area. The questionnaire included both open-ended and fixed response questions. Open-ended questions were included to convey information on knowledge about wildlife in the area and whether wildlife posed problems to the community.

A series of supplementary questions was also used in the questionnaire to gather personal and socio-economic information at the level of individual respondents. The interview was conducted in eight randomly selected villages. Villages were selected based on the information gathered using the pilot survey. These were: Abergina, Gich, Mecheka-Tikurwuha, Kiflo, DabaJohna, Deguale, Zinababre, and Woizero Mesk (Fig. 1). Gich village was located in the Park whereas Deguale, Zinababre, and Woizero Mesk were further away from the Park boundary $(\sim 35$ $\mathrm{km})$. The remaining villages were located within the buffer zone (within the range of 1 to $5 \mathrm{~km}$ ). The interviewees were selected on the basis of first come first serve basis (Newmark et al., 1993). 


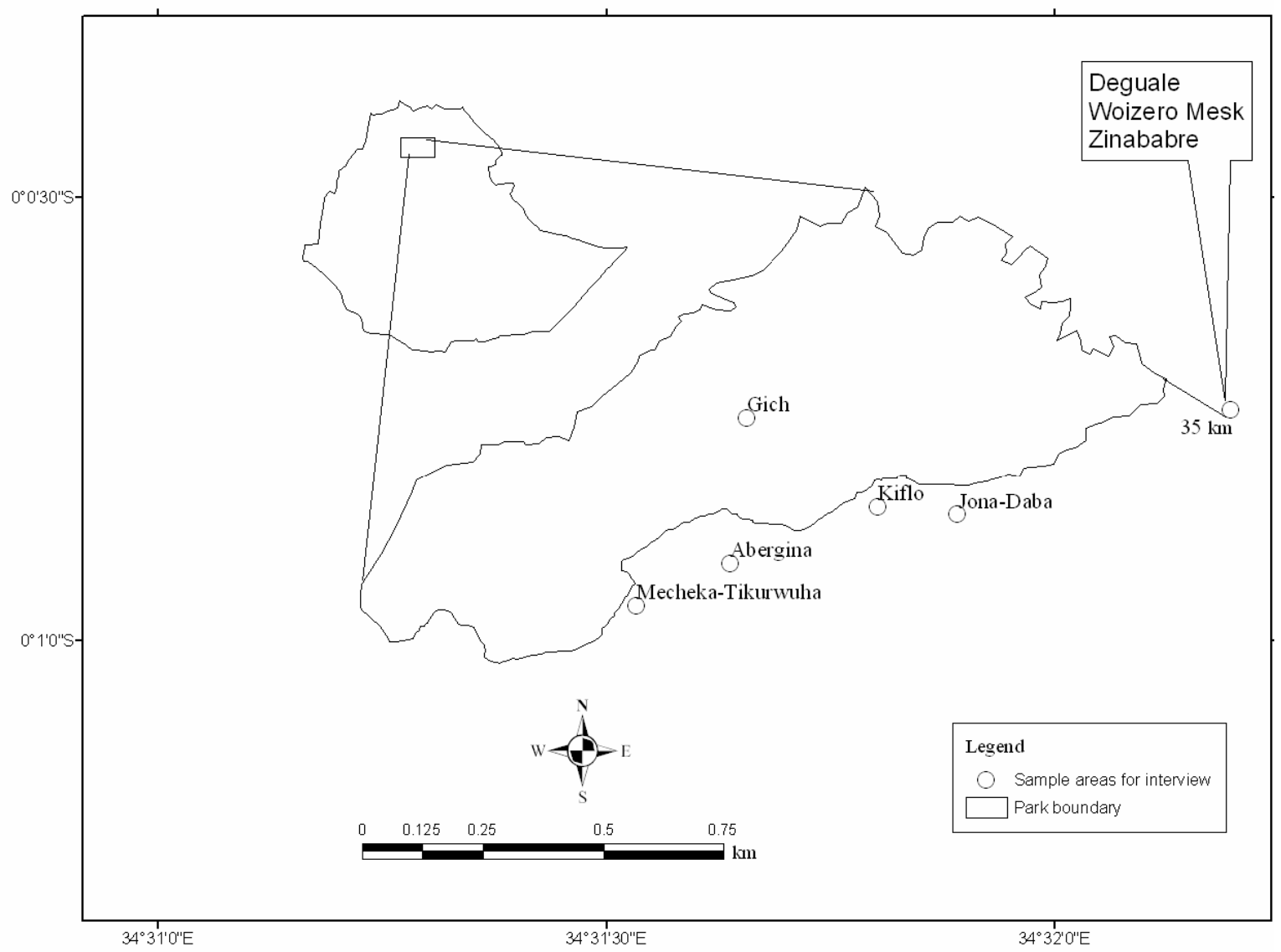

Fig. 1. Map showing the location of the Simien Mountains National Park and the study sites

\section{Data analysis}

Data were analysed using descriptive statistics and responses were compared using chi-square test and one-way ANOVA. Logistic regression was used to determine which factors (site of grazing, distance from the Park, family size, size of livestock and size of farmland) might be important in determining the problems caused by wildlife.

\section{RESULTS}

Predation by the common jackal over the past ten years was reported by $57.1 \%$ of the respondents. The main prey type was sheep $(54.7 \%)$ and there was less $(2.4 \%)$ predation on goats. The average loss of sheep to common jackals per year per household was $1.14 \pm 0.06$. Villages differed $\left(x^{2}=\right.$ 33.5 , d.f. $=7, p<0.001)$ on the reported loss of sheep and goats to the common jackal. Most predation from Abergina (78.6\%), MechekaTikurwuha $(60 \%)$, Gich $(73.7 \%)$ and Jona-Daba $(70.5 \%)$ was carried out by common jackals (Table 1 ). On the other hand, the average sheep loss to the Ethiopian wolf per year per household was $0.62 \pm$ 0.09 . The probability of sheep loss to the Ethiopian wolf per year per household was estimated to be $0.2 \%$.

Table 1. Loss of sheep and goats to common jackal in different villages.

\begin{tabular}{llll}
\hline Village & $\begin{array}{l}\text { No. of } \\
\text { respondents }\end{array}$ & No $(\%)$ & $\begin{array}{l}\text { Yes } \\
(\%)\end{array}$ \\
\hline Abergina & 42 & 21.4 & 78.6 \\
Mecheka-Tikurwuha & 35 & 40.0 & 60.0 \\
Gich & 37 & 26.3 & 73.7 \\
Kiflo & 44 & 29.5 & 70.5 \\
Jona-Daba & 42 & 52.4 & 47.6 \\
Deguale & 34 & 69.7 & 30.3 \\
Woizero Mesk & 33 & 63.6 & 36.4 \\
Zinababre & 33 & 51.5 & 48.5 \\
& & & \\
Total & 300 & 43.0 & 57.0 \\
\hline
\end{tabular}

Out of the total predation, sheep loss by hamadryas baboon was $5.3 \%$ and goats $1.4 \%$ in the study area during the last ten years. Hamadryas is not only a predator but also a crop raider, resulting in bi-directional damage to the local community. Only $6.7 \%$ of the respondents reported loss of sheep and goats to hamadryas baboons. There was a significant difference $\left(X^{2}=82.9\right.$, d.f. $=21, p<$ 
0.001) among villages in terms of predation by hamadryas baboon. $40 \%$ of the respondents from Mecheka-Tikurwuha and $14.3 \%$ from Abergina reported loss of sheep and goats to hamadryas baboons.

Total loss of domestic animals to leopard, common jackal, hyaena and hamadryas baboon was $9.0 \%, 57.1 \%, 27.2 \%$ and $6.7 \%$, respectively. Villages also significantly differed $\left(\chi^{2}=83.8\right.$, d.f. $=$ $7, p<0.001)$ in terms of predation of sheep and goats by leopard. Among the eight villages, 45.7\% of the total predation by leopard was recorded in Mecheka-Tikurwuha village (Table 2).

Table 2. Loss of sheep and goats to leopard among different villages.

\begin{tabular}{llll}
\hline Village & $\begin{array}{l}\text { No. of } \\
\text { respondents }\end{array}$ & No $(\%)$ & $\begin{array}{l}\text { Yes } \\
(\%)\end{array}$ \\
\hline Abergina & 42 & 78.6 & 21.4 \\
Mecheka-Tikurwuha & 35 & 54.3 & 45.7 \\
Gich & 37 & 100.0 & 0.0 \\
Kiflo & 44 & 97.7 & 2.3 \\
Jona-Daba & 42 & 97.6 & 2.4 \\
Deguale & 34 & 100.0 & 0.0 \\
Woizero Mesk & 33 & 100.0 & 0.0 \\
Zinababre & 33 & 100.0 & 0.0 \\
& & & \\
Total & 300 & 91.0 & 9.0 \\
\hline
\end{tabular}

The main prey items predated in the study area by the spotted hyaena (Crocuta crocuta) were horses $(9.6 \%)$, oxen $(8.0 \%)$, cows $(5.4 \%)$, sheep $(2.6 \%)$, donkeys $(0.8 \%)$ and mule $(0.6 \%)$. More horses were predated as a result of their high population size. Loss of domestic animals to spotted hyaena was $27 \%$ during the last ten years. There was a significant difference $\left(X^{2}=85.6\right.$, d.f. $\left.=14, p<0.001\right)$ among villages in terms of loss of livestock to spotted hyaena. Kiflo reported $65.9 \%$ loss of livestock to the spotted hyaena. On the other hand, none from Woizero Mesk or Zinababre reported the loss of livestock to spotted hyaenas (Table 3).
Table 3. Loss of livestock to the spotted hyaena among different villages.

\begin{tabular}{llll}
\hline Village & $\begin{array}{l}\text { No. of } \\
\text { respondents }\end{array}$ & No $(\%)$ & $\begin{array}{l}\text { Yes } \\
(\%)\end{array}$ \\
\hline Abergina & 42 & 57.1 & 42.9 \\
Mecheka-Tikurwuha & 35 & 88.6 & 11.4 \\
Gich & 37 & 52.6 & 47.4 \\
Kiflo & 44 & 34.1 & 65.9 \\
Jona-Daba & 42 & 78.6 & 21.4 \\
Deguale & 34 & 90.9 & 9.1 \\
Woizero Mesk & 33 & 100.0 & 0.0 \\
Zinababre & 33 & 100.0 & 0.0 \\
& & & \\
Total & 300 & 73.0 & 27.0 \\
\hline
\end{tabular}

Gelada baboons were the most significant pests in the study area. The average crop loss by gelada baboon per household per year was $117 \pm 10 \mathrm{~kg}$. There was a positive correlation $(r=0.43, p<0.001)$ between the type of crop grown and the type of damage. Loss of barley by gelada baboons was $47.3 \%$. The remaining proportion constituted crops such as wheat, oat, linseed, bean and pea. In addition, a large proportion $(99.71 \pm 81.3 \mathrm{~kg})$ of barley was damaged on the field. There were also other crop pests in the study area but they were not considered as such significant pests. These are: hamadryas baboon (Papio hamadryas), vervet monkey (Cercopithecus aethiops) and crested porcupine (Hystrix cristata). The average crop loss due to these animals in the study area in 2005 was $42 \pm 8 \mathrm{~kg}$. These animals had different level of pest status based on their frequency of damage. Crop loss to hamadryas was $6.5 \%$, whereas, it was $7.2 \%$ to vervet monkeys and $0.4 \%$ to porcupines (Table 4). Hamadryas baboons and vervet monkey mainly damaged barley, wheat, beans and peas. However, porcupines only consumed potatoes in the study area.

Table 4. Percentage of respondents suffering crop loss caused by pest animals.

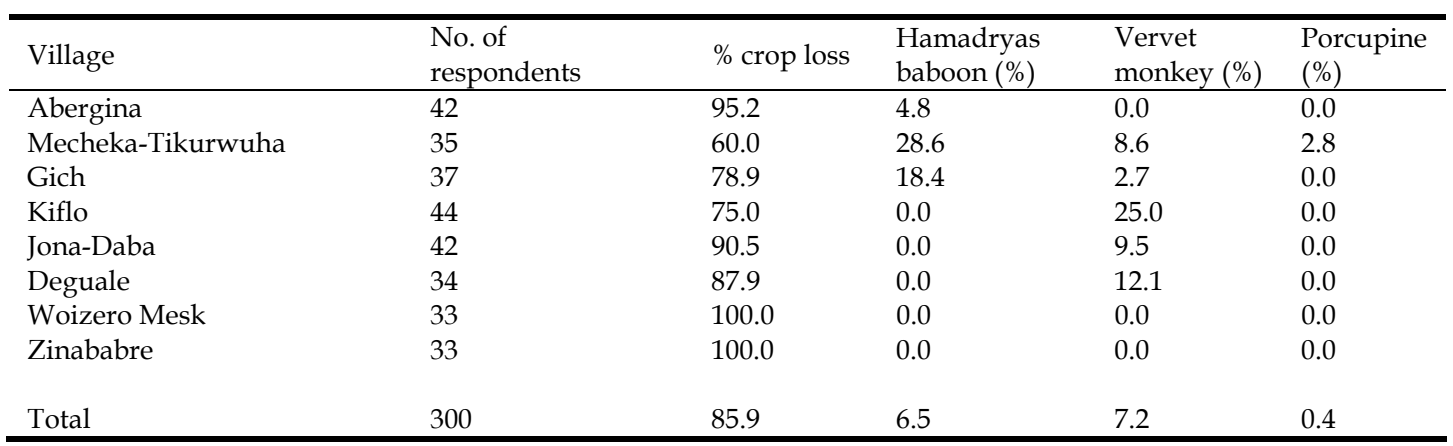


The trend of human population increase in and around the Simien Mountains National Park is shown in Fig. 2. At present, the human population density in the study area is greater than 100 individuals per $\mathrm{km}^{2}$. The community living in and around the Park utilised the Park as grazing land for their livestock. Those that are living closer to the park utilized the resources throughout the year.

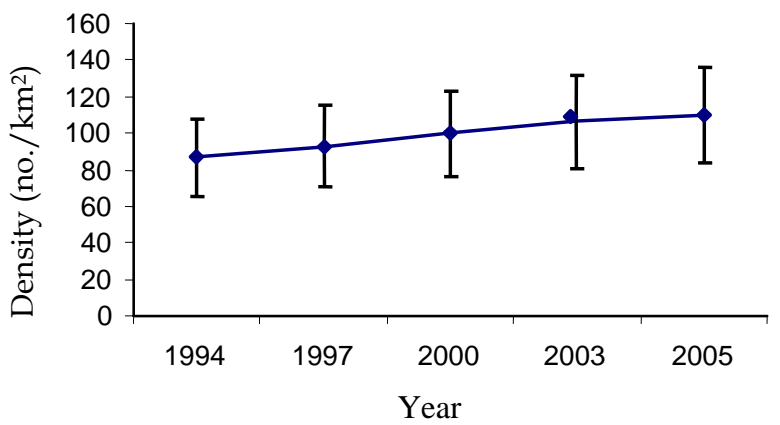

Fig. 2. Change in population density of people living in and around the Simien Mountains National Park. (Source: CSA, 1995 and Kebele Administration).
The General Linear Model for the factors to determine problems caused by wildlife was explained by $52.7 \%$ variance and the likelihood ratio goodness of fit test just fitted the model $(p<$ 0.001). Proximity of villages to the park, site of grazing and the number of sheep were important factors in determining the problems caused by wildlife. Mecheka-Tikurwuha and Abergina villages faced more problems caused by wildlife than others (Table 5).

Nearly, half $(47.9 \%)$ of the respondents utilized the Park as grazing land for their livestock. There was a significant difference $(F,=93.69$, d.f. $=7,292$, $p<0.001)$ among villages in using the Park as a grazing land. Using Tukey test, the mean rate of utilizing the Park as grazing land in Jona-Daba was compared with Deguale $(p<0.001)$, Woizero Mesk $(p<0.001)$ and Zinababre $(p<0.001)$. JonaDaba utilized the Park as a grazing land most while Deguale, Woizero Mesk and Zinababre did not utilize it at all (Table 6).

Table 5. Factors that determine the problems caused by wildlife using logistic regression.

\begin{tabular}{lllll}
\hline Variables & $\mathrm{B}$ & $\mathrm{SE}$ & $\mathrm{df}$ & Significance \\
\hline Village & & & 7 & $0.001^{* *}$ \\
Abergina & 2.32 & 0.88 & 1 & $0.008^{* *}$ \\
Mecheka-Tikurwuha & 3.18 & 1.11 & 1 & $0.004^{* *}$ \\
Gich & -0.51 & 1.08 & 1 & 0.633 \\
Kiflo & 1.94 & 1.24 & 1 & 0.117 \\
Jona-Daba & 1.27 & 1.37 & 1 & 0.351 \\
Deguale & -0.56 & 0.57 & 1 & 0.320 \\
Woizero Mesk & -0.09 & 0.56 & 1 & 0.866 \\
Zinababre & 0 & - & - & 0 \\
Grazing (inside the park) & -2.56 & 0.99 & 1 & $0.010^{*}$ \\
Number of sheep & 0.24 & 0.06 & 1 & $0.000^{* * *}$ \\
Constant & 1.97 & 1.11 & 1 & 0.074 \\
\hline
\end{tabular}

Note: Level of significance shown with * $=\mathrm{P}<0.05,{ }^{* *}=\mathrm{P}<0.01$ *** $=\mathrm{P}<0.001$

Table 6. Loss of sheep and goats to leopard among different villages.

\begin{tabular}{lccc}
\hline \multicolumn{1}{c}{ Village } & $\begin{array}{c}\text { No. of } \\
\text { respondents }\end{array}$ & $\begin{array}{c}\text { Grazing in the park } \\
(\%)\end{array}$ & $\begin{array}{c}\text { Grazing outside the park } \\
(\%)\end{array}$ \\
\hline Abergina & 42 & 69.0 & 31.0 \\
Mecheka-Tikurwuha & 35 & 31.4 & 68.6 \\
Gich & 37 & 92.1 & 7.9 \\
Kiflo & 44 & 93.2 & 6.8 \\
Jona-Daba & 42 & 97.6 & 2.4 \\
Deguale & 34 & 0.0 & 100.0 \\
Woizero Mesk & 33 & 0.0 & 100.0 \\
Zinababre & 33 & 0.0 & 100.0 \\
& & & 52.1 \\
\hline
\end{tabular}


The average period of utilization of the Park as grazing land was $2.03 \pm 0.11$ months with a range of grazing period in the Park from 2-12 months. Villages differed significantly in the number of months they used the Park for grazing purposes ( $F=118.7$, d.f. $=7,292, p<0.001)$. Using the Tukey test, the mean number of months for grazing in JonaDaba was compared with Deguale $(p<0.001)$, Woizero Mesk $(p<0.001)$ and Zinababre $(p<0.001)$. Jona-Daba utilized more months than others (Table 7). The duration of grazing in the Park was negatively correlated $(\mathrm{r}=-0.69, p<0.05)$ with distance from the Park.

The community living in and around the SMNP used different types of plant species and cow dung as firewood. Some of the utilized plant species were heather, Erica arborea, St. John wort, (Hypericum revolutum), eucalyptus leaves, Acacia abyssinica, giant lobelia (Lobelia rhynchopetalum), olive tree (Olea spp.), Rumex studli, and red hot pocker (Kniphofia foliosa and K. comosa). Villages differed $\left(X^{2}=89\right.$, d.f., $\left.7, p<0.001\right)$ in area from which firewood is collected. Most respondents (63.6\%) from Kiflo and some respondents from Mecheka-Tikurwuha (20\%), Gich (21.1\%), JonaDaba (40.5\%) but few respondents from Abergina (7.1\%) collected firewood from the Park (Table 8).

Collection of firewood was negatively correlated with distance from the Park $(r=-0.33, p<0.001)$. But, there was no correlation between frequency of firewood collection and family size $(\mathrm{r}=0.11, p>$ $0.05)$.

\section{DISCUSSION}

Among the different predators, common jackal and spotted hyaena were considered as more problematic to the community living in and around the SMNP than others. This fits with the general perception that smaller canids such as jackals, coyotes and feral dogs are more problematic than large canids like grey wolves and African wild dogs (Sillero-Zubiri and Switzer, 2004). The common jackal is one of the major problematic predators in the study area. Sheep loss to common jackals was reported by $57.1 \%$ of the respondents. Research conducted in Golan (Israel) showed that $70 \%$ of the attacks were carried out by Jackals (Yom-Tov et al., 1995). The high proportion of sheep loss to common jackal possibly is due to the high number in the study area and the method of keeping livestock by farmers. Many communities did not have well built houses and fences to protect their livestock against predators. Hence, common jackals and leopards could easily penetrate the fences and drag out the sheep. So, most of the predation by leopard happened during the night but predation by jackal occurred both during the night and day time within the settlement.

Table 7. Duration of grazing in the Park in different villages.

\begin{tabular}{|c|c|c|c|c|c|c|}
\hline Village & $\begin{array}{c}\text { No. of } \\
\text { respondents }\end{array}$ & $\begin{array}{l}\text { Never } \\
\text { uses \% }\end{array}$ & $\begin{array}{c}1-3 \\
\text { months }\end{array}$ & $\begin{array}{c}4-6 \\
\text { months }\end{array}$ & $\begin{array}{c}\text { 7-9 } \\
\text { months }\end{array}$ & $\begin{array}{l}\text { 10-12 } \\
\text { months }\end{array}$ \\
\hline Abergina & 42 & 31.0 & 0.0 & 4.8 & 7.1 & 57.1 \\
\hline Mecheka-Tikurwuha & 35 & 68.6 & 2.9 & 17.1 & 0.0 & 11.4 \\
\hline Gich & 37 & 7.9 & 0.0 & 0.0 & 0.0 & 92.1 \\
\hline Kiflo & 44 & 6.8 & 0.0 & 0.0 & 0.0 & 93.2 \\
\hline Jona-Daba & 42 & 2.4 & 0.0 & 0.0 & 0.0 & 97.6 \\
\hline Deguale & 34 & 100.0 & 0.0 & 0.0 & 0.0 & 0.0 \\
\hline Woizero Mesk & 33 & 100.0 & 0.0 & 0.0 & 0.0 & 0.0 \\
\hline Zinababre & 33 & 100.0 & 0.0 & 0.0 & 0.0 & 0.0 \\
\hline Total & 300 & 52.1 & 0.36 & 2.7 & 0.9 & 43.9 \\
\hline
\end{tabular}

Table 8. Firewood collection from within and outside the Park among villages.

\begin{tabular}{lrrr}
\hline \multicolumn{1}{c}{ Village } & $\begin{array}{c}\text { No. of } \\
\text { respondents }\end{array}$ & Outside the park (\%) & Within the park (\%) \\
\hline Abergina & 42 & 92.9 & 7.1 \\
Mecheka-Tikurwuha & 35 & 80.0 & 20.0 \\
Gich & 37 & 78.9 & 21.1 \\
Kiflo & 44 & 36.4 & 63.6 \\
Jona-Daba & 42 & 59.5 & 40.5 \\
Deguale & 34 & 100.0 & 0.0 \\
Woizero Mesk & 33 & 100.0 & 0.0 \\
Zinababre & 33 & 100.0 & 0.0 \\
& & & 19.1 \\
Total & 300 & 80.9 & \\
\hline
\end{tabular}


The average sheep loss to the Ethiopian wolf per year per household was $0.62 \pm 0.09$. The reason for the lower sheep loss to the Ethiopian wolf is that the distribution of the Ethiopian wolf is very limited and its population is also very low in the study area; and it largely feeds on rodents. The other carnivore that caused problem to the local community in the study area was leopard (Panthera pardus). Only $9 \%$ of the respondents reported sheep loss to leopard. Similarly, a study in Annapurna Conservation Area (Nepal) showed that snow leopard (P. uncia) was reported to kill livestock in most parts of its range (Oli et al., 1994). In the present study, $45.7 \%$ of the respondents from Mecheka-Tikurwuha and 21.4\% from Abergina reported sheep loss to leopard. The possible reason could be the high distribution of leopards around these villages. Spotted hyaena is another predator in the study area. Among the respondents, $27 \%$ reported the loss of domestic animals to spotted hyaena. Some respondents accepted the loss of livestock to spotted hyaena as a result of carelessness by the owner. Unless the livestock is left in the field unattended, spotted hyaenas do not dare to approach human settlements and attack livestock.

Hamadryas baboons were also pests in the area. However, their effect was not serious compared to the common jackals. Only $6.7 \%$ of the respondents reported the loss of sheep and goats to hamadryas baboons. Among villages, $40 \%$ of the respondents from Mecheka-Tikurwuha reported loss of sheep and goats to hamadryas baboons. Hamadryas baboons also appeared to be crop raiders in the study area. However, this conflict was restricted to Mecheka-Tikurwuha and Abergina villages. This was possibly because such villages were very near to the lowland area, the major habitat for the animals. Vervet monkeys and crested porcupines were also crop pests in the study area. But they were not serious pests due to their minimal number. In contrast to this, according to Naughton-Treves (1998), primates accounted 48\% of the total damage to crops around Kibale National Park. In addition, a study in Nanda Devi Biosphere Reserve (India) showed that porcupines and monkeys were major wildlife pests responsible for crop damage (Rao et al., 2002).

In Africa, the major problem facing protected areas today is the increase in human settlement of adjacent lands and unauthorized harvesting of resources within the protected areas (Newmark et al., 1993). Human population has increased continuously in and around the SMNP (Fig. 2). This high human population has its own impact on the wildlife population. As human population increases, encroachment also increases resulting in resource exploitation. This can easily be observed by increase in livestock grazing in the Park. Many respondents $(47.9 \%)$ reported that they utilized the Park for livestock grazing. The amount of time for grazing in the Park is negatively correlated with distance from the Park. Decreasing distance of the Park from villages increased the frequency of time for grazing inside the Park. Large proportion of respondents from Abergina, Gich, Kiflo, and JonaDaba villages reported that the period for grazing their livestock inside the Park was between 10-12 months. Inhabitants nearby the Park played a greater role in habitat destruction. Similarly, as reported by Zelealem Tefera (2001), livestock from nearby villages stayed longer in the Guassa area than from villages far away.

Firewood collection is another type of exploitation which has a detrimental effect in the study area. $19.1 \%$ of the respondents reported that they collected firewood from the Park. Even though it is not pronounced like livestock grazing, it had a significant impact on habitat quality by removing shrubby vegetation, an important habitat and source of fodder for some species of mammals such as rodents. Similarly, fuel wood and wildlife resources were exploited by the community in Baboon Sanctuary in Belize with significant impacts (Hartup, 1994). Firewood collection is negatively correlated with distance from the Park. Those who lived closer to the Park collected firewood more frequently than those who lived far from the Park. Similar results were also observed on the study conducted in Guassa area: peasant associations closer to the area used firewood more frequently than those living further away (Zelealem Tefera, 2001).

Local people have been practising firewood collection for millennia. This activity has resulted in extreme erosion and formation of gullies in some areas. The fertility of the land has been decreasing gradually from year to year (Hartup, 1994). The output of crop obtained is decreasing over time, pushing the farmers to cultivate more land. As a result, increase in cultivation inside the Park and the buffer zone is frequently observed. This has resulted in a continuous land clearing leading to habitat fragmentation and decrease in the abundance and diversity of species in the Park and the surrounding areas. Therefore, unless immediate action is taken to minimize the problem, maintaining the biodiversity of the area will be bleak. In addition, there must be more restoration of tree cover like Eucalyptus and 
Juniperus to minimize soil loss and provide a sustainable source of firewood; more use of hydroelectric or solar power to reduce use of firewood; better use of the lower land by irrigation/water storage in order to reduce the pressures at high altitude.

\section{ACKNOWLEDGEMENTS}

We are grateful to the Frankfurt Zoological Society (FZS) and Addis Ababa University for providing funding and space. Special thanks go to the Amhara Regional State Park Administration and Development Authority for allowing us to conduct the research in the Simien Mountains National Park

\section{REFERENCES}

1. CSA (1995). The 1994 Population and Housing Census of Ethiopia, Results of Amhara Region. Central Statistics Authority (CSA), Addis Ababa, Ethiopia.

2. Deresse Dejene (2003). Attitudes and Perception of Local Community towards the Ethiopian Wolf. (MSc. Thesis). Durrell Institute of Conservation and Biology (DICE). University of Kent.

3. Falch, F. and Keiner, M. (2000). Simien Mountains National Park Management Plan. Final draft (unpublished). Amhara National Regional State, Bahir Dar.

4. Hartup, B.K. (1994). Community conservation in Belize: Demography, resource use, and attitude of participating land owners. Biol. Conserv. 69:235-241.

5. Hurni, S.J. (1986). Management Plan: Simien Mountains National Park and surrounding rural area. UNESCO World Heritage Committee, Switzerland.

6. Hurni, H. and Ludi, E. (2000). Reconciling Conservation with Sustainable Development. University of Berne, Switzerland.

7. Kristin, S.S. and Struhsaker, T.T. (1999). Colobus Monkeys and Coconuts: a study of perceived human-wildlife conflicts. J. App. Ecol. 36:10091020.
8. Messmer, T.A. (2000). The Emergence of HumanWildlife Conflict Management: Turning Challenges into Opportunities. Inter. Biodetr. 45:97-102.

9. Mulonga, S., Suich, H. and Murphy, C. (2003). The Conflict Continues: Human-Wildlife Conflict and Livelihoods in Caprivi. Windhoek, Namibia.

10. Naughton-Treves, L. (1998). Predicting Pattern of Crop Damage by Wildlife around Kibale National Park, Uganda. Conserv. Biol. 12(1):156168.

11. Newmark, W.D., Leonard, N.L. Sarko, H.I. and Gemassa, D.M. (1993). Conservation Attitude of Local People Living Adjacent to Five Protected Areas in Tanzania. Biol. Conserv. 63:177-183.

12. Oli, M.K., Taylor, I.R. and Rogers, M.E. (1994). Snow Leopard Panthera unica Predation of Livestock: An Assessment of Local Perception in the Annapurna Conservation Area, Nepal. Biol. Conserv. 68:63-68.

13. Rao, K.S., Maikhuri, R.K., Nautiyal, S. and Saxena, K.G. (2002). Crop Damage and Livestock Depredation by Wildlife: A Case Study from Nadavi Biosphere Reserves, India. J. Envt. Mgmt. 66(3):317-327.

14. Sillero-Zubiri, C. and Switzer, D. (2001). Crop Raiding Primates: Searching for Alternative, Humane Ways to Resolve Conflict with Farmers in Africa. People and Wildlife Initiative. Wildlife Conservation Research Unit, Oxford University.

15. Sillero-Zubiri, C. and Switzer, D. (2004). Management of Wild Canids in Human Dominated Landscapes. People and Wildlife Initiative. Wildlife Conservation Research Unit, Oxford University.

16. Sukumar, R. (1989). The Asian Elephant. Cambridge University Press, Cambridge.

17. Yom-Tov, Y., Ashkenazi, S. and Viner, O. (1995). Cattle Predation by the Golden Jackal Canis aureus in the Golan Heights, Israel. Biol. Conserv. 73: 19-22.

18. Zelealem Tefera (2001). Common Property Resource Management of an Afro-Alpine Habitat: Supporting a Population of a Critically Endangered Ethiopian Wolf (Canis simensis). $\mathrm{PhD}$. Thesis. Durrel Institute of Conservation and Ecology. University of Kent, Kent. 